\title{
A Typological Approach to Translation of English and Chinese Motion Events
}

\author{
Yu Deng ${ }^{1} \&$ Huifang Chen ${ }^{2}$ \\ ${ }^{1}$ School of Foreign Languages, Leshan Normal University, China \\ ${ }^{2}$ Xiamen Institute of Technology Huaqiao University, China \\ Correspondence: Yu Deng, School of Foreign Languages, Leshan Normal University, Leshan, Sichuan, China. \\ Tel: 86-182-8337-8958. E-mail: adam611@163.com
}

\author{
Received: April 7, 2012 Accepted: April 23, 2012 Online Published: July 2, 2012 \\ doi:10.5539/elt.v5n8p70 URL: http://dx.doi.org/10.5539/elt.v5n8p70
}

The research is financed by Academic Projects of Leshan Normal University (No: 2011-S1119, JG11-YB09).

\begin{abstract}
English and Chinese are satellite-framed languages in which Manner is usually incorporated with Motion in the verb and Path is denoted by the satellite. Based on Talmy's theory of motion event and typology, the research probes into translation of English and Chinese motion events and finds that: (1) Translation of motion events in English and Chinese is a re-lexicalization process; (2) For translation of Path, English-Chinese translators can usually convert Path verbs in English into Path satellites in Chinese and vice versa for Chinese-English translation. Translation of continuous and complex Path is a lexical conversion between pattern [Motion] +

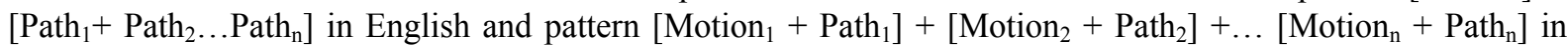
Chinese; (3) For translation of Manner, Chinese-English translation tends to replace the structure of [Chinese adverbial + Motion verb] with the corresponding Manner-conflating verb in English, while English-Chinese translation has to add adverbial to the Chinese verb or use general Chinese Manner verbs to encode the specific Manner verbs in English; (4) Different narrative styles and conceptualization of time and space in both languages should be taken into consideration in translation of English and Chinese motion events.
\end{abstract}

Keywords: translation, motion events, typology, English, Chinese

\section{Introduction}

Talmy approaches conceptualization of languages through schematic systems, which include configurational structure, location of perspective point, distribution of attention, force dynamics and cognitive state. Event of motion, which involves space and time, belongs to configurational structure. Talmy defines the semantic structure of motion event as:

$$
\text { [Figure Motion Path Ground } \left.]_{\text {Motion event }} \leftarrow \text { Relation [Event }\right]_{\text {co-event }}
$$

The basic motion event consists of one object (the Figure) moving or located with respect to another object (reference object or Ground). Besides Figure and Ground, there are Path and Motion. The Path is the path followed or site occupied by the Figure object with respect to the Ground object. The component of Motion refers to the presence of motion or locatedness in the event (Talmy, 2000b: 25). But most languages express the core event of motion together with a co-event, which relates to the main motion event as its cause or as its manner, but it's actually a whole range: its precursor, its subsequences and so forth (Li\& Gao, 2010: 347).

In motion event, the Path component functions as the core schema to frame the entire event at semantic level. According to different ways of rendering Path at surface level, world languages can be categorized into two types: Languages that characteristically map the core schema (Path) into the verb will be said to be verb-framed languages, including Romance, Semitic, Japanese, Tamil, etc. Languages that characteristically map the core schema (Path) into satellite are said to be satellite-framed languages, including English, Chinese, Finno-Ugric, and Indo-European minus Romance. The satellite is a grammatical category of any constituent other than a nominal or prepositional-phrase complement that is in a sister relation to the verb root. It can be either a bound affix or a free word, encompassing all of the following grammatical forms: English verb particles, German 
separable and inseparable verb prefixes, Latin or Russian verb prefixes, and Chinese verb complements (Talmy, 2000b: 222).

According to Talmy's typology, English and Chinese are both satellite-framed languages, which regularly use satellites to specify Path and incorporate Manner with Motion in the verb. However, there are also some differences between English and Chinese motion events concerning the specific semantic elements of Manner and Path. Therefore, translation of English and Chinese motion events should be based on the differences between English and Chinese encoding of Path and Manner. This paper aims at how the Path and Manner in English and Chinese are translated based on typological properties.

\section{Translation of Path}

The satellites in English are mostly involved in the expressions of Path. Some basic Path satellites in English are in, out, across, up, along, down, above, past, by, below, over, off, aside, away, ahead, back, around, etc. Chinese also has Path satellites and constructions that are entirely homologous with those of English (Talmy, 2000b:105-109). Like 去thither, 过across/past, 来hither, 起up off, 上up, 掉off, 下down, 走away, 进in, 回 back, 出out, 拢together, 到all the way (to), 开apart/free, 散ascatter.

\subsection{Chinese-English Translation of Path}

Besides Path satellites, English also has a number of verbs that incorporate Path, important examples are enter, exit, ascend, cross, pass, circle, advance, proceed, approach, arrive, depart, return, join, separate, part, rise, leave, follow(Talmy, 2000b:52). In addition, verbs like wind, zigzag, stream, course, etc are more concrete incorporations of Path element and all contain the Path of the object in motion. However, Chinese tends to use the satellite to indicate Path, so Chinese-English translators can change the Path satellites in Chinese into Path verbs in English for most cases, while seldom the Chinese Path satellites also have corresponding Path satellites in English. For example:

(1) 环湖路上, 连那个抗癌明星的身影也见不到了。

As he skirted the lake shore, he did not see the cancer-battling celebrity.

(2) 他在人群里找了几圈, 没有找到…..

He circled the crowd several times, searching in vain for his family...

(3) 蛇怒, 退身出。

Furiously the snake backed out of the hole...

(Examples (1)-(3) are quoted from Liu\& Li, 2009)

(4) 祝英台也慢慢走下了假山。

Yingtai slowly descended the hill. (quoted from Chen, 2010)

In example (1), the preposition phrase 环湖路上huán hú lù shàng indicates the Path of motion although the involved motion is invisible, but English translator can take a Path verb skirted without satellite in the target language to successfully activate the equivalent. In example (2), the times of motion 几圈ji quān can enable the translator to infer the Path of this motion event, and the round Path in the source language is lexicalized into Path verb in the target language. In example (3) and (4), Chinese structure of [verb root + directional complement] is used to express Motion + Manner + Path of motion events. 出chū and Fxià respectively express Path of the movement, while 退tui and 走zǒu respectively express the Manner. In example (3), translator can conflate the adverbial out of (including direction and Path) into the verb in target text. To some extents, the target text encodes the corresponding Path satellite in the source text. Example (4) applies a Path verb descend (it means move down) in target text to express both Motion and Path in source text regardless of Manner. Translation method of example (4) is more formal and fit for literature translation.

\subsection{English-Chinese Translation of Path Information}

Similarly, In English-Chinese translation of Path, translators can convert Path verbs in English into Path satellites in Chinese. For example:

(5) He ascended the flight of narrow stairs to his bedroom. 他登上狭窄的楼梯到他的卧室去。

(6) The boy ascended the ladder. 这男孩爬上了梯子。

(7) When they ascended the steps to the hall, Maria's alarm was every moment increasing, and even Sir 
William did not look perfectly calm.

他们踏上台阶走进穿堂的时候, 玛丽亚一分钟比一分钟来得惶恐, 连威廉爵士也不能完全保持 镇定。

(8) Victoria ascended the throne in 1839.

维多利亚于一八三九年登上王位。

(9) She descended the stairs.

她走下楼梯。

(10) The balloon descended gradually as the air came out. 气球空气外逸而缓缓下降。

(11) "But surely," said she, "I may enter his county with impunity, and rob it of a few petrified spars with out his perceiving me."

她说: “我一定可以大摇大摆地走进他的故乡, 趁他不知不觉的时候, 㩲取几块透明的晶石。”

(Examples (5)-(11) are quoted from http://www.luweixmu.com/ec-corpus/query.asp)

In the above examples, Path verbs ascended, descended, enter are used in source texts to express Motion and Path. Ascended in Example (5), (6) and (7) means climb up, while ascended in example (8) conveys a HIGH STATUS IS UP metaphor, when someone ascends a throne, they become king, queen, or pope. In example (9), the Path verb descended means go down while in example (10) descended means fall down. In example (11) enter means go into. In the target text, the Path verbs ascended, descended, enter are respectively translated into pattern [Verb+Path satellite] like 登上 dēng shàng, 爬上pá shàng, 踏上tà shàng, 走下zóu xià, 下降xià jiàng, 走进 zón jìn. In the target text, the motion verbs like 登dèng, 爬pá, 踏tà, 降jiàng, 走zón are taken to denote motion and manner, while the Chinese satellites 上shàng、下 xid 、进 $j$ in are taken to denote Path.

Due to different styles of narrative in English and Chinese, Path elements vary greatly in English-Chinese translation process especially in the frame of continuous and complex motion events. For example:

(12) "Coming!" Away she skimmed over the lawn, up the path, up the steps, across the veranda, and into the porch...

“来啦! ”她转身蹦着跳着地跑了, 越过草地, 跑上小径, 跨上台阶, 穿过凉台, 进了门廊。 (quoted from Shao, 2006)

(13) And then the little thing flew like a bird downstairs with her cakes and out of the house. 小家伙像小鸟一样飞下楼梯, 飞出了房子。(quoted from Chen, 2010)

In the description process, English tends to take the static style, while Chinese encoding of event is more dynamic, so in the translation of example (12) and (13), English takes the syntactic form of $\left[\right.$ Verb + satellite $_{1}+$ satellite $_{2}+\ldots$ satellite $\left._{n}\right]$ while Chinese syntactic form is encoded as $\left[\mathrm{VP}_{1}+\mathrm{VP}_{2}+\ldots \mathrm{VP}_{\mathrm{n}}\right]$. Specifically, skimmed (Motion) away over...up ...across...and into in the source text of example (12) is translated into 进了 jìn le......跑上 páo shàng....... 跨过 kuà guò......穿过 chuān guò......越过 yuè guò in the target text, the syntactic conversion is done based on the typological properties of lexicalization in source language and target language. This is also true of example (13) in which the syntactic form in the source text flew...downstairs... and out of is translated into 飞下fêi xià...... 飞出fêi chü in the target text. The conversion of Path elements is from [Motion] $+\left[\right.$ Path $_{1}+$ Path $_{2} \ldots$ Path $\left._{n}\right]$ in English (source language) to $\left[\right.$ Motion $_{1}+$ Path $\left._{1}\right]+\left[\right.$ Motion $_{2}+$ Path $\left._{2}\right]+\ldots$ $\left[\right.$ Motion $_{n}+$ Path $\left._{n}\right]$ in Chinese (target language). From this translation process, it can be seen that in English-Chinese translation of motion event, we can change the whole Path in the source text into different parts of Path in the target text, and vice versa. The motivation for such kind of change between English and Chinese is that English attaches more importance to the natural time and space while Chinese places more attention on the psychological domain of time and space. Therefore, different conceptualization of time and space should be considered in the translation of English and Chinese motion events.

\section{Translation of Manner}

\subsection{English-Chinese Translation of Manner Information}

English is a language rich in Manner-conflating verbs, such as burst, dart, plunge, race, rush, skitter, scud, sprint, stroll, saunter, brush, glide, slip, sneak, slink, skulk, march, plod, stamp, step, stride, strut, tiptoe, limp, hobble, dodder, stagger, shuffle, trip, climb, clamber, crawl, creep, scramble, slither, jump, hop, leap, spring, bounce(Li, 2008). In contrast, there are some correspondents in Chinese for the mentioned English Manner verbs like 跑

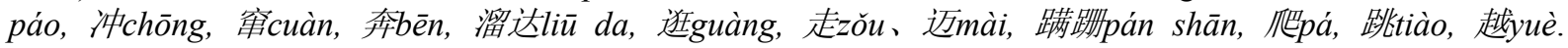
But Chinese has less Manner verbs than English. In that case, free translation is adopted in the translation of 
English-Chinese motion events. Specifically, to add adverbials to the verb in Chinese is a good choice in translating the English Manner verbs which have no correspondents in Chinese. For example:

(14) I drive to work everyday. 我每天开车去上班。

(15) I flew to Hawaii last Month. 上个月我坐飞机去了夏威夷。

(16) The truck roared across the town. 车轰鸣着穿过小镇。

(17) The bullet whistled into the room. 子弹嗖地进了房间。(Examples (14)-(17) are quoted from Li, 2008)

(18) She rustled out of the room. 她走出房间，衣裙沙沙作响。(quoted from Shao, 2006)

For the English Manner verbs in examples (14)-(18), there are no correspondents in Chinese, so in the English-Chinese translation process, a phrase is adopted to decode the meaning in the source texts, and a [Chinese adverbial + Motion verb] pattern is encoded in the target text to convey the same semantic meaning. Say, in example (14) and (15), drive to work and flew to Hawaiii in the source text are respectively translated as 开车去上班(drive a car to go to work) and 坐飞机去夏威夷 (take a airplane to go to Hawaii) in the target text. In example (16), (17) and (18), the concomitant sounds in movement is lexicalized in the target texts, say, roared in (16) is encoded as 轰鸣着穿 (go through with big sound). In example (17), whistled into the room is encoded as 嗖地进了房间(enter the room with a swoosh). In (18), rustled out of the room is encoded as 走出房间,衣裙 沙沙作响(exited the room, accompanied by the swing rustle of her clothing). Adding a Chinese adverbial to the Motion verb in the target text would highlight the Manner information in the lexicalization. From these examples, it can be inferred that English focuses more on syntactic complexity while Chinese highlights more on descriptive detail, and this typological variation should be highly noted in the English-Chinese translation.

Although most translators can add adverbial to Chinese verbs in English-Chinese translation of specific Manner and in most cases this method can preserve the vivid Manner in the source text, there are still some problems for this translation technique. For instance, the target text may not be as concise as the source text, and the target text may overemphasize the Manner information in the source text. To make a balance, translators can use the general Chinese verbs like走zǒu, 跑paó, 跳tiào etc to replace the concrete Manner verbs in English. For example:

(19) All the time he was jerking out these phrases, he was stumping up and down the tavern on his crutch. 在他急切地讲这一番话的时候, 他一直架着拐杖在小酒馆里跳来跳去。

(20) The squire, at this, would turn away and march up and down the deck, chin in air. 一听到这个,乡绅就会背过脸去,在甲板上走来走去,下巴㲐明上天。

(21) The captain was too bright to be in the way. He whipped out of sight in a moment, leaving Silver to arrange the party; and I fancy it was as well he did so.

船长太明智了,决不碍他们的事。他一转眼就走开了,留下了西尔弗他们,由西尔弗来安排;我想他 这样做也好。

(22) With all this in our minds, we waded ashore as fast as we could, leaving behind us the poor jolly boat, and a good half of all our powder and provisions.

我们带着所有这些想法,尽快地向岸上跑去,身后擞下了那只可怜的划子,还有一大半的弹药和给 养。(Examples (19)-(22) are quoted from Li, 2008)

Examples (19)-(22) are the translation of the same literature discourse Treasure Island, the Manner verbs stump, march, whip and wade in the source texts are very concrete, and there are no corresponding Manner verbs in Chinese. Therefore, the general Chinese Manner verbs like 跳tiào, 走zǒu, 跑paó are adopted in the target text to encode the Manner information in the source text regardless of the concrete Manner information in each sentence. Note that these sentences have the same discourse context; the general Manner verbs can still reflect the key message in the source text although there are no specific Manner verbs in target text.

In English-Chinese translation of Manner element, the different inter-linguistic models of lexicalization usually 
lead the translators to a dilemma, so we had better combine the method of general Manner verb replacement with the method of [Chinese adverbial + Motion verb] encoding, and make a reasonable selection according to the specific context.

\subsection{Chinese-English Translation of Manner Information}

The Chinese-English translation of Manner information tends to replace the structure of [Chinese adverbial + Motion verb] in the source text with the corresponding Manner-conflating verb in the target text or replace the same Chinese Manner verb with different English Manner verbs because there are far more concrete Manner verbs in English than in Chinese. For example:

（23）我看见他戴着黑布小帽, 穿着背部大马补, 深青布棉袄, 蹒跚地走到铁道边, 慢慢探下身去, 尚不大难...

I watched him hobble towards the railway track in his black skullcap, black cloth mandarin jacket and dark blue cotton-padded cloth long gown. (quoted from Zhang, 1999: 63-67)

（24）他在房间里摇摇灵晃地走着, 很显然他已喝醉了。

He was staggering across the room and had obviously had a few.

(25) 那老太太拖著脚步走过房间。

The old lady shuffled across the room.

（26）受伤的足球队员跛著脚慢慢走出埸地。

The injured footballer limped slowly off the field.

(27) 在黑暗中, 我看见有个身影悄悄走出去。

In the darkness, I saw a shape tiptoeing out.

(28) 女孩悄悄地离开了家。

The girl glided from the house.

（29）我没有注意汤姆从我后面偷偷走了上来。

I didn't notice tom sneaking up behind me.

(30) 我注意到一个陌生人在村子的街上溜达。

I noticed a stranger strolling the street of the village.

(31) 孩子们爬过岩石。

The children scrambled over the rocks.

(32) 他偷了钱后从房子里溜了出去。

He stole the money and sneaked out of the house.

(33) 谈话中稍一停顿他就溜了出去.

He slipped out during a pause in the conversation.

(34) 她冲到门口躲藏起来。

She darted into the doorway to hide.

(Examples (24)-(34) are quoted from http://www.luweixmu.com/ec-corpus/query.asp)

Examples (23)-(34) show the colorful lexicalization of English Manner verbs in encoding the same semantic category of Chinese Manner verbs. The Manner verbs in the source texts are more general and they have the similar movement schema according to human's experience of moving forward. In other words, the Manner verbs in the source text of (23)-(34) can all be replaced by the general Chinese Manner verbs like 走 zǒu. But in the target text of (23)-(34), different concrete Manner verbs are adopted to correspond to the general Chinese Manner verbs like 走 zŏu in each specific source text, and in the target text various satellites like towards, across, off, out, from, up, over, into are combined with each concrete Manner verb like hobble, staggering, shuffled, limped, tiptoeing, glided, sneaking, strolling, scrambled, sneaked, slipped, darted to conflate different Manner information.

The difficulty for Chinese-English translation of motion events is how to construal the same motion event with different lexicalizations, so translators must realize the lexicalization of the same motion event varies from one language to anther. Translators can not just simply carry on the same lexicalization pattern of the source 
language, but go through a re-lexicalization process according to the cognitive requirement of the target language.

\section{Conclusion}

English and Chinese are typical members of satellite-framed languages in which Path is denoted by the satellites while Manner is usually incorporated with Motion in the verbs. The basic event of Motion is universal for both languages, but there are also typological properties for the semantic elements of Path and Manner in English and Chinese motion events. This research has a general exploration about the translation of English and Chinese motion events based on typological properties, and it is found that: (1) Translation of motion events in English and Chinese is a process of re-lexicalization, translators should attach importance to the inter-linguistic conflation of Path, Manner in both languages; (2) For translation of Path, English-Chinese translators can convert Path verbs in English into Path satellites in Chinese and vice versa for Chinese-English translation. Translation of continuous and complex Path is a lexicalization conversion between pattern [Motion] $+\left[\mathrm{Path}_{1}+\right.$ Path $_{2} \ldots$ Path $\left._{n}\right]$ in English and pattern $\left[\right.$ Motion $_{1}+$ Path $\left._{1}\right]+\left[\right.$ Motion $_{2}+$ Path $\left._{2}\right]+\ldots\left[\right.$ Motion $_{n}+$ Path $\left._{n}\right]$ in Chinese; (3) For translation of Manner, Chinese-English translation tends to replace the structure of [Chinese adverbial + Motion verb] with the corresponding Manner-conflating verb, while English-Chinese translation has to add adverbial to the verb in Chinese or use general Manner verbs to encode the specific Manner verbs in English; (4) Translation of English and Chinese motion events should also consider the different narrative styles and conceptualization of time and space in both languages.

\section{References}

Chen, H. F. (2010). A Contrastive Study of English and Chinese Encoding of Motion Events. Unpublished MA Dissertation. Huaqiao University.

Li, F. Y., \& Gao, Y. (2010). (Eds). Ten Lectures on Cognitive Semantics by Leonard Talmy. Beijing: Foreign Language Teaching and Research Press.

Li, X. (2008). Variations of the Lexicalization Patterns of Motion Verbs in English and Chinese and Its Influence on Translation. Foreign Language Research, 6, 109-112.

Liu, H. W., \& Li, H. Q. (2009). Re-lexicalization in Chinese-English translation of motion event. Foreign Language Teaching and Research, 5, 379-385.

Shao, Z. H. (2006). An applied contrastive study on the expression of English and Chinese motion event-frames. Journal of Foreign languages, 2, 33-40.

Talmy, L. (1985). Lexicalization Patterns: Semantic Structure in Lexical Forms. In Timothy Shopen (Eds.), Language Typology and Syntactic Description: Grammatical Categories and the Lexicon. Vol. 3. Cambridge: Cambridge.

Talmy, L. (1991). Path to Realization: A Typology of Event Conflation. Proceedings of the Seventeenth Annual Meeting of the Berkeley Linguistics Society. Berkeley Linguistic Society.

Talmy, L. (2000a). Toward a Cognitive Semantics, Volume I: Concept Structuring Systems. Cambridge: MIT Press.

Talmy, L. (2000b). Toward a Cognitive Semantics, Volume II: Typology and Process in Concept Structuring. Cambridge: MIT Press.

Zhang, P. J. (1999). Selected Modern Chinese Prose Writings. Shanghai: Shanghai Foreign Language Education Press.

\section{Authors}

Yu Deng, English Teacher of Leshan Normal University, Master's Degree, research field: Cognitive Linguistics.

Huifang Chen, English teacher of Xiamen Institute of Technology Huaqiao University, Master's Degree, research field: Cognitive Linguistics. 